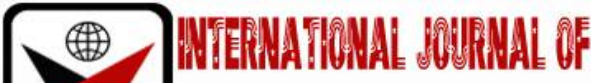

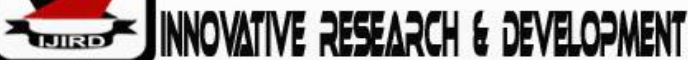

ISSN 2278-0211 (Online)

\section{Equifinality of Flood Determinants in the Wetlands of Lagos State, Nigeria}

\begin{tabular}{c} 
Ajijola Saudat $\mathbf{0 .}$ \\
Ph.D. candidate, Department of Architecture, Caleb University, Lagos, Nigeria \\
John Bello \\
Senior Lecturer, Department of Architecture, Caleb University, Lagos, Nigeria \\
Olatunde Arayela \\
Professor, Department of Architecture, Caleb University Lagos, Nigeria \\
\hline
\end{tabular}

\begin{abstract}
:
Flooding is natural in wetland ecosystems and urbanization is sprawling into wetlands of Lagos city. Flood prevention and management strategies through structural interventions have not yielded the desired result. The environmental determinist's argument that nothing is free of the influence of the environment comes to fore. This study focuses on understanding ecosystem peculiarity and man's influential role at intelligently and adaptively building with nature for ecosocial sustainability. The research method employs a mixed method sequential explanatory design. In the first phase, a mailed survey collected the following data $(n=116)$ in June 2020 from ten residential communities within Kosofe local government area of Lagos state: the attributes of the flooding experienced, causes of flood occurrences, and factors influencing occurrence of floods. In the second phase, equifinality is used to explain the results of analysis of the quantitative data. Findings reveal that 'flooding' as an end state may occur from different initial states and in different ways, based on dynamic interaction in the environment. In conclusion, an objective approach to sustainability is one founded on acknowledging the importance of the ideologies of environmental determinism and possibilism. While it is common for the environment to set constraints, man has the choice to intelligently journey with sustainability towards a fulfilling and equitable future.
\end{abstract}

Keywords:Adaptive urban design, eco-social sustainability, environmental determinism, environmental possibilism, equifinality, flooding

\section{Introduction}

Man and nature have shared a complex, dynamic and mutually inclusive relationship that may be difficult to grasp. While the environmental determinist exonerates man and postulates that man is a passive agent, who is controlled by geography, climate and his surroundings; the possibilist argues that although nature sets the limit; man is an active agent who is at liberty to explore possibilities through technology and adjust the environment to his specification. The irony is that man is still influenced by his modified environment.

For centuries, aspects of physical geography particularly climate has been taught to influence human psychology, behavior and culture (Andrew, 2003). There are no doubts that climate influences food production, lifestyle choices, human health and well-being as well as disease transmission (George, 2009). Even today, public health response to the novel coronavirus pandemic is rooted in environmental adaptation through social distancing and compulsory use of nose mask to limit the spread of the virus (WHO, 2019).

The ideology that man is constrained to behave in a certain way by his environment has been at the center of one of the longest debates in the history of the social science and geography (Beck, 1985). Environmentalists argue that nothing is free of the influence of the environment (Singh, 2007). And there is considerable evidence that suggests the natural environment has played a fundamental role in human development because so many human characteristics may be interpreted as rooted in adaptations to natural phenomena.

Yet, the ideology that the natural environment predates all human behavior is unnatural to man's freewill and his power to choose the pattern of human activity on earth. In reality, anthropogenic activities are shaping human culture and systems impacting the natural ecosystem, human health and wellbeing in fundamental ways. Although, technological innovations have tremendous social and economic impact on human existence, it is often accompanied by significant adverse environmental impact. For instance, industrialization has had major impact on air, water, soil and the habitat resulting in global warming, pollution, ocean acidification, soil contamination and extinction of rare plant and animal species. Also, growing global human population which is projected to reach 9.7 billion in 2050 (UN World population prospects, 2019) is threatening the sustainability of natural resources. 
This does not mean that all prevailing environmental challenges are solely based on anthropogenic influences. There are naturally occurring disasters (wildfire, tornadoes, floods, hurricanes, earthquakes, pandemic diseases etc.) that pose as much threat (Kolsrud and Torrey. 1991). Yet the public is quick to link extreme events with climate change caused by human activities. A critical study on climate evolution suggest that human societies have experienced climate change since the development of agriculture some 10,000 years ago ranging from annual and decadal climate fluctuations to the large-scale magnitude changes that occur over centennial to multi-millennial timescales (Solomon et al. 2007). The progression of climate over the past millennial includes three typical periods namely; the medieval warming period (A.D. 900-1300), the little ice age (A.D. 1550-1850), and the 20th century global warming (Wang et al. 2002). These three periods were driven by different factors. The medieval warming was documented to have been caused by increased solar activity, decreased volcanic activity, and changes to ocean circulation; thus resulting in increased air temperature; on the other hand, the 20th century warming resulted from atmospheric accumulation of greenhouse gasses especially carbon dioxide, CO2 emitted through human activities (Zhou, T., et. al. (2011). The continued disparity between the ideologies of environmental determinism and possibilism has a serious effect on eco-social sustainability.

The environment is a complex open system with diverse interacting agents or variables that cause emergent behavior (Frankel, 1992). Currently, flooding is a common environmental phenomenon which can be directly linked to both natural and anthropogenic causes. In Lagos, Nigeria; flooding is a complex incessant occurrence with devastating impacts on residents despite several efforts and studies aimed at addressing the problem (Aderogba, (2012), Abolade, et.al. 2013). The first record of flooding in Lagos was in July 1947; an event occasioned by a period of heavy rainfall (Daily times, 1947). Afterwards, flooding events have been documented to occur almost every year particularly during the rainy season resulting in the loss of lives; destruction of buildings and properties; loss of soil from valuable farmland, disruption of socio-economic activities as well as the transmission of waterborne diseases (Oyebande, 1974; Ayoade \& Akintola, 1980; Action Aid, 2006; Adeloye \& Rustum, 2011; Etuonovbe, 2011; Aderogba, 2012a; Odunuga et al., 2012; Oshodi, 2013; Adelekan, 2013; Ajibade et al., 2013, 2014; Soneye, 2014, Nkwunonwo et. al, 2016). Despite the frequency of flood events and severity of the associated impacts, understanding of the intricacies in the causes of flooding is still very limited. Perhaps a major factor is the evasive nature of the determinants of flood occurrences in the city. Lagos is both a coastal and urbanized city. About $40 \%$ of the city's total land area is made up of wetlands and water bodies with lagoons and creeks consisting of $22 \%$ of its area (Oteri \& Ayeni, 2018). The natural terrain and physical characteristics of major parts of the city naturally supports flooding. On the other hand, to keep up with growing population, urban development is sprawling into coastal wetlands; changing land-use and modifying natural land covers. Increase in impervious surfaces associated with these anthropogenic influences also supports flooding. However, urban planners are quick to conclude that flooding in Lagos is as a result of non-adherence with the city's master plan in which provisions have been made for drainages. Although structural solutions are suitable in controlling the flow of water, they have also shown numerous drawbacks. This study is conducted on the strength of the fore mentioned and the need to begin to look towards adaptive non-structural solutions born out of an objective understanding of ecosystem peculiarity and processes.

\subsection{Aim and Objectives of Study}

The study aims at fostering an objective understanding of environmental complexities and challenges by exploring the processes leading to flooding so as to evolve workable and sustainable solutions. The investigation was focused on residential areas within Kososfe local government area of Lagos state.

To achieve the goal set out in this research, the following objectives are considered;

- To analyze the attributes of flooding experienced in the study area

- To evaluate the causes of flood occurrences

- To examine the factors influencing recurrent flooding events

- To apply the general systems theory of equifinality to qualitatively analyze the quantitative field results.

\section{Methodology}

Research methods adopt the use of the general systems theory of equifinality to explain the complexities associated with the processes leading to flooding in urbanized and built-up land in wetlands and flood plains.

\subsection{Study Area and Site}

The study was conducted in Kosofe local government area (LGAs) of Lagos state (6.6010N, 3.4090E; 4m elevation.) which is blessed with wetland ecosystem that has undergone significant spatial changes from rapid urbanization and unplanned development. It has an area of $81 \mathrm{~km} 2$ and a population of 682,772 people with 358,935 males and 323,887 females at the national population census. Kosofe's climate is characterized as tropical savanna wet (Köppen climate classification). Ten communities within and around the floodplain are examined. They include Ajegunle, Irawo, Idera, Owode-Onirin, Thomas, Weigh Bridge, Ajelogo, Agboyi, Magodo and Ikosi Isheri. The areas have similar temperature and precipitation pattern characterized by two rainy seasons with the heavier downpour from April to July and the lighter from September to November. There is an August break usually characterized by a relatively dry season and a longer dry season from December to March. The predominant vegetation of the study area is the tropical swamp forest although the area is completely built up today. Geologically, the area lies within Dahomey Sedimentary Basin and belongs to the Coastal Plain Sands, which incorporates exposures of sedimentary rocks, ranging from silt, clay and fine to coarse grain sand. 


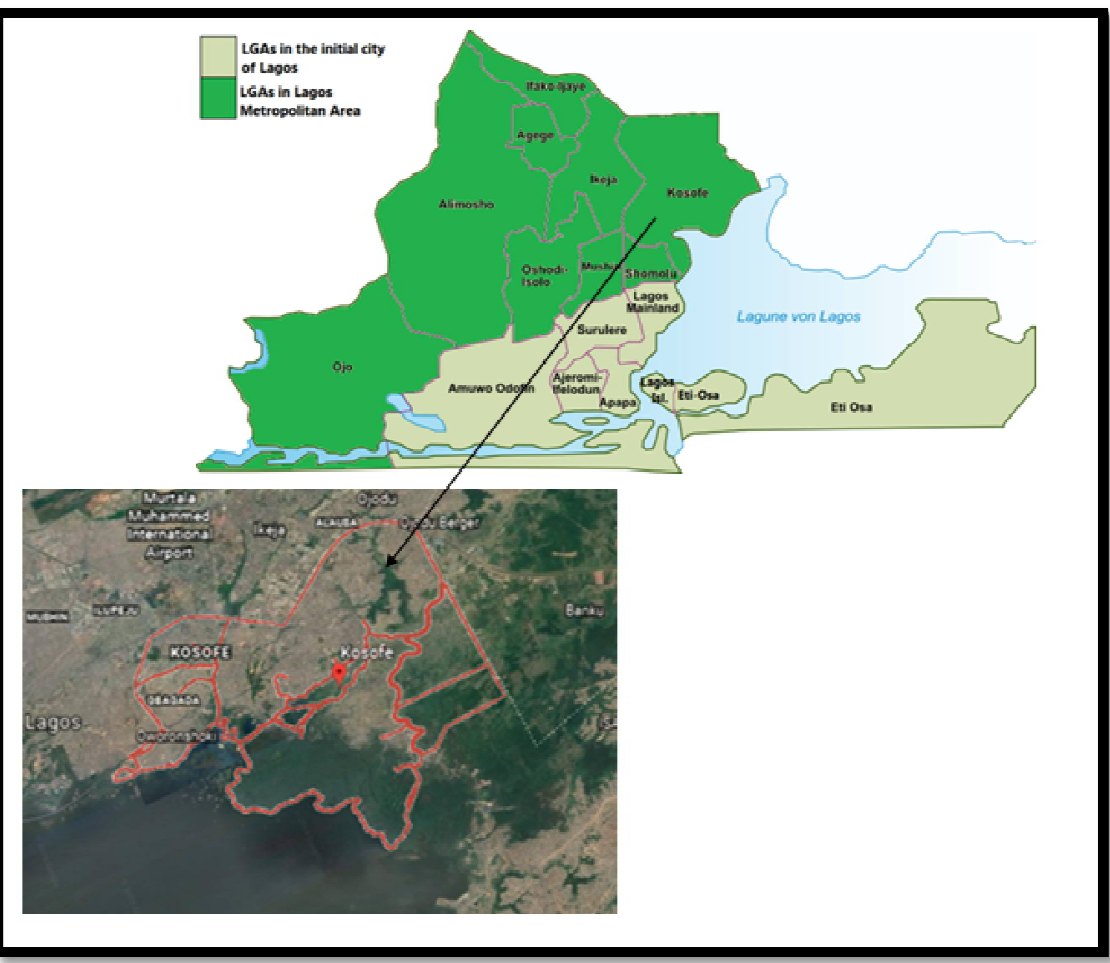

Figure 1: Map of Study Area Source: Google Earth

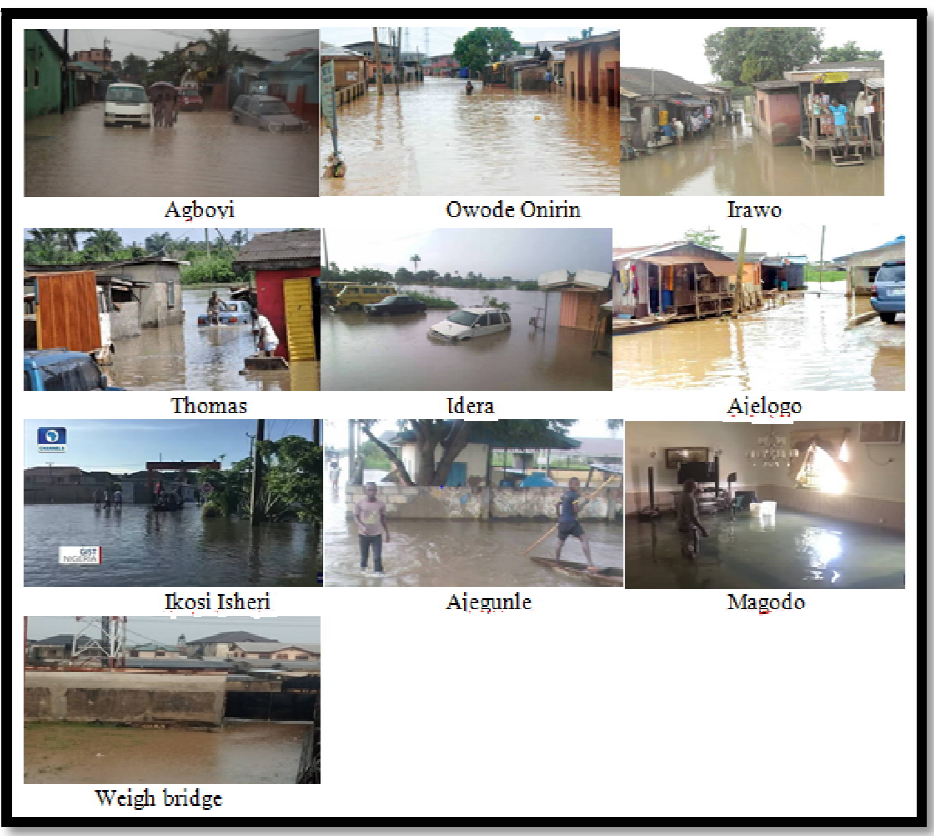

Figure 2: Pictures from Study Area

Source: Author's Field Survey

\subsection{Study Design}

The research method employs a mixed method sequential explanatory design. This approach has two distinct phases: quantitative followed by qualitative (Creswell, Plano Clark, et al., 2003). In the first phase, a well-structured closeended questionnaire was administered randomly to one hundred and sixteen (116) residents and business owners within the study by mail. To secure the respondent's empathy, information and links to the survey were systematically shared when the study areas were flooded. Results of the quantitative data are analyzed using frequency and percentage distribution. In the second phase, the general systems theory of equifinality is used to explain results of the quantitative data.

\subsubsection{Development of the Quantitative Survey Instruments}

The questionnaire contained information on the socio-economic characteristics of respondents (age, gender, education qualification); the characteristics of the flooding pattern experienced; perceptions on the main cause of flooding and determinants of flood risks. 


\section{Analysis and Discussions}

\subsection{Socio Economic Characteristics of Respondents}

\begin{tabular}{|c|c|c|c|c|c|c|c|c|c|c|c|c|c|c|c|c|}
\hline & \multicolumn{2}{|c|}{ Sex } & \multirow{2}{*}{\multicolumn{3}{|c|}{ Age Group (years) }} & \multirow{2}{*}{\multicolumn{5}{|c|}{ Highest Level of education }} & \multirow{2}{*}{\multicolumn{3}{|c|}{$\begin{array}{l}\text { Nature of } \\
\text { Occupancy }\end{array}$}} & \multicolumn{3}{|c|}{$\begin{array}{c}\text { Land } \\
\text { Acquisition }\end{array}$} \\
\hline & \multirow[b]{2}{*}{$\frac{0}{\sum^{\pi}}$} & \multirow[b]{2}{*}{$\begin{array}{c}\frac{0}{\widetilde{\widetilde{U}}} \\
\underset{0}{0} \\
{[}\end{array}$} & & & & & & & & & & & & \multirow{2}{*}{ 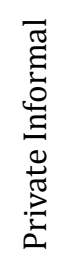 } & \multirow{2}{*}{ 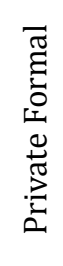 } & \multirow[b]{2}{*}{$\frac{.0}{2}$} \\
\hline & & & $\begin{array}{l}18- \\
25\end{array}$ & $\begin{array}{c}26- \\
60\end{array}$ & $\begin{array}{c}\text { Above } \\
60\end{array}$ & 苞 & 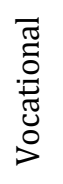 & 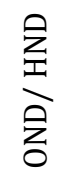 & Un & 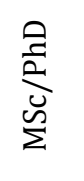 & 完 & 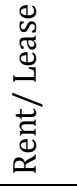 & $\stackrel{\dot{\Xi}}{\check{\Xi}}$ & & & \\
\hline Frequency & 61 & 55 & 20 & 75 & 21 & 22 & 6 & 13 & 50 & 25 & 29 & 77 & 10 & 101 & 7 & 8 \\
\hline Total & \multicolumn{2}{|c|}{116} & \multicolumn{3}{|c|}{116} & \multicolumn{5}{|c|}{116} & \multicolumn{3}{|c|}{116} & \multicolumn{3}{|c|}{116} \\
\hline$\%$ & 52.6 & 47.4 & 17.2 & 64.7 & 18.1 & $\begin{array}{l}18 . \\
9\end{array}$ & 5.2 & $\begin{array}{l}11 . \\
2\end{array}$ & 43.1 & 21.6 & 25 & 66.4 & 8.6 & 87.1 & 6 & 6.9 \\
\hline Total & \multicolumn{2}{|c|}{100} & \multicolumn{3}{|c|}{100} & \multicolumn{5}{|c|}{100} & \multicolumn{3}{|c|}{100} & \multicolumn{3}{|c|}{100} \\
\hline
\end{tabular}

Table 1: Socio Economic Characteristics of Respondents

Source: Author's Field Survey

Analysis of survey indicates that $52.6 \%$ of the respondents are male while the remaining $47.4 \%$ are female. A glance at the age distribution of respondents as shown in Table 1 indicates that the modal class is in the age group 26 - 60 years with 64.7 percent. About $17.2 \%$ and $18.1 \%$ fall above and below the modal class respectively. The educational status of the sampled respondents is relatively above average with all respondents having a minimum secondary school certificate. As shown in Table 1, 18.9\% had only SSCE; 5.2\% attained vocational training; $11.2 \%$ graduated from polytechnics while $43.1 \%$ and $21.6 \%$ graduated from the universities with a bachelor's and post graduate degree respectively.

On the nature of occupancy, $25 \%$ of the respondents are owner occupiers while $66.4 \%$ are either on rent or lease. The remaining $8.6 \%$ are occasional visitors or former residents of the area. Owner occupiers acquired land for housing development from various means. As indicated in Table 1, 87.1 acquired land in private informal market through private purchase from original owners, members of land-owning families. 6\% acquired their land through private formal deals from organized land developers while $6.9 \%$ sourced their landed property from the state government through statutory allocation.

\subsection{Characteristics, Causes and Flood Risk Factors in Study Area}

Appraising the flood patterns, 67 percent reported severe streets flooding of extended duration that last for a couple of days while others indicated home flooding and severe compound flooding of extended duration. Also, 53 percent stated that most flooding starts within the first three hours (1-3 hrs.) after the start of an intense rain. 40 percent and 7 percent indicated (4- $9 \mathrm{hrs}$.) and (10 hrs. above) respectively. It is observed from the field that most of the areas under survey experience serious flooding after normal and above normal rainfall.

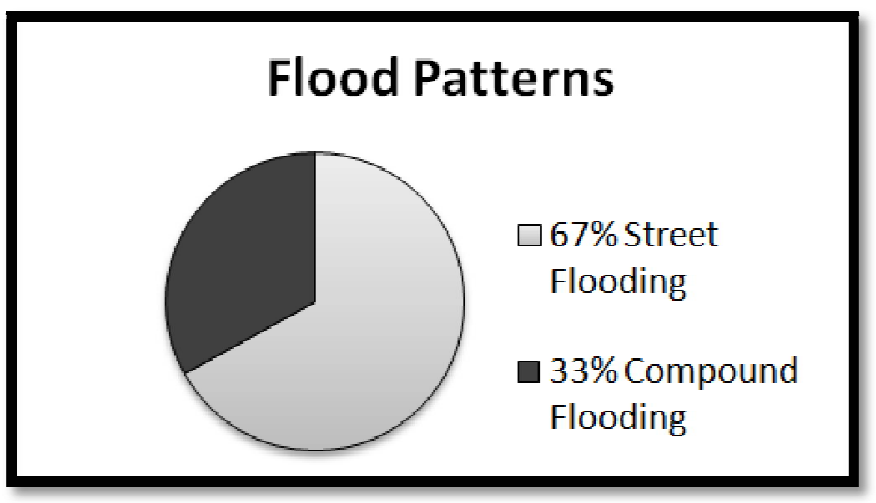

Figure 3: Flood Patterns

Source: Author's Field Survey 


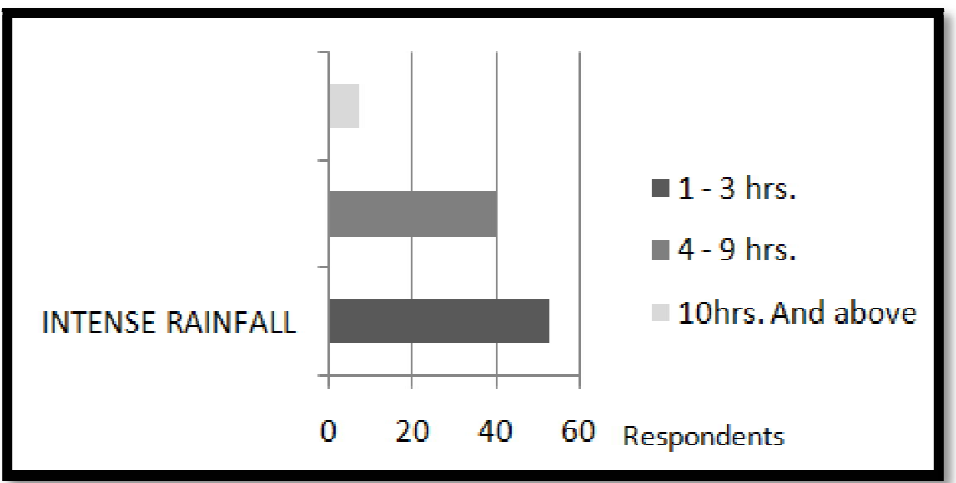

Figure 4: Time Flood Starts after an Intense Downpour Source: Author's Field Survey

\begin{tabular}{|c|c|c|c|c|c|c|c|c|c|c|c|c|c|c|c|c|c|c|}
\hline \multirow[b]{3}{*}{ 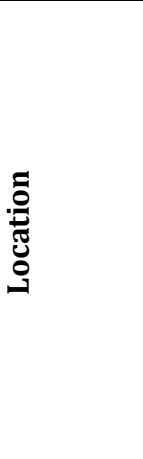 } & \multirow{3}{*}{ 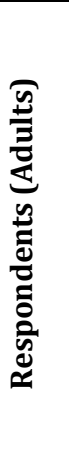 } & \multicolumn{5}{|c|}{$\begin{array}{c}\text { Major Causes Of } \\
\text { Flooding Experienced }\end{array}$} & \multirow{2}{*}{\multicolumn{3}{|c|}{$\begin{array}{l}\text { Time Flooding } \\
\text { Occurs After Intense } \\
\text { Rainfall Starts }\end{array}$}} & \multicolumn{9}{|c|}{ Factors Influencing Occurrence Of Floods } \\
\hline & & \multirow[b]{2}{*}{ 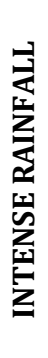 } & \multirow[b]{2}{*}{ 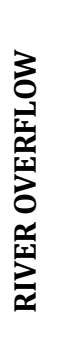 } & \multirow[b]{2}{*}{ 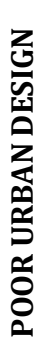 } & \multirow[b]{2}{*}{ 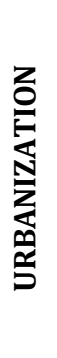 } & \multirow[b]{2}{*}{ 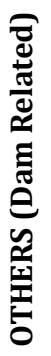 } & & & & \multirow[b]{2}{*}{ 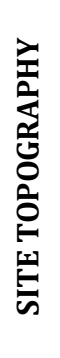 } & \multirow[b]{2}{*}{ 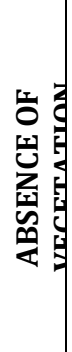 } & \multirow[b]{2}{*}{ 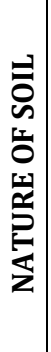 } & \multirow[b]{2}{*}{ 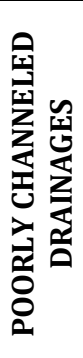 } & \multirow{2}{*}{ 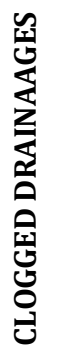 } & \multirow[b]{2}{*}{ 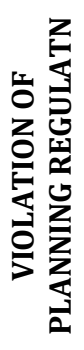 } & \multirow{2}{*}{ 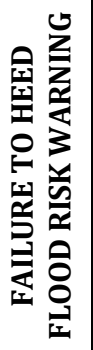 } & \multirow[b]{2}{*}{ 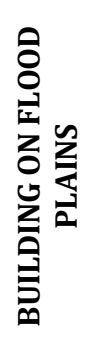 } & \multirow[b]{2}{*}{ 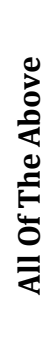 } \\
\hline & & & & & & & $\underset{\dot{c}}{m}$ & $\begin{array}{l}\dot{m} \\
\dot{c} \\
a \\
\dot{q}\end{array}$ & 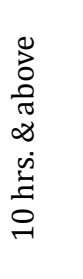 & & & & & & & & & \\
\hline Magodo & 14 & 5 & - & 4 & 4 & 1 & 2 & 10 & 2 & - & - & - & 8 & 4 & - & - & - & 2 \\
\hline $\begin{array}{l}\text { Ikosi } \\
\text { Isheri }\end{array}$ & 6 & 2 & - & 3 & 1 & - & 1 & 5 & - & - & - & - & 6 & - & - & - & - & - \\
\hline Agboyi & 11 & 1 & 2 & 6 & 1 & 1 & 3 & 7 & 1 & 1 & - & - & 7 & 2 & - & - & 1 & - \\
\hline Ajelogo & 5 & 2 & - & 2 & 1 & - & - & 3 & 2 & - & - & - & 4 & 1 & - & - & - & - \\
\hline $\begin{array}{l}\text { Owode } \\
\text { Onirin }\end{array}$ & 6 & 3 & - & 2 & - & 1 & 2 & 3 & 1 & - & - & - & 6 & - & - & - & - & - \\
\hline Idera & 12 & 4 & 1 & 5 & 2 & - & 7 & 5 & - & - & - & - & 7 & 3 & 2 & - & - & - \\
\hline Irawo & 21 & 6 & 1 & 11 & 2 & 1 & 15 & 6 & - & - & 1 & - & 9 & 8 & - & 1 & 2 & - \\
\hline $\begin{array}{l}\text { Weigh } \\
\text { bridge/ }\end{array}$ & 8 & 1 & - & 4 & 1 & 2 & - & 6 & 2 & - & - & - & 5 & 3 & - & - & - & - \\
\hline Thomas & 15 & 2 & 1 & 9 & - & 3 & 14 & 1 & - & - & - & - & 3 & 12 & - & - & - & - \\
\hline Ajegunle & 18 & 4 & 5 & 6 & 1 & 2 & 18 & - & - & - & 2 & - & 11 & 3 & - & - & 2 & - \\
\hline TOTAL & 116 & 30 & 10 & 52 & 13 & 11 & 62 & 46 & 8 & 1 & 3 & - & 66 & 36 & 2 & 1 & 5 & 2 \\
\hline
\end{tabular}

Table 2: Characteristics, Causes and Flood Risk Factors in Study Area

Source: Author's field survey

Also, findings from the survey suggest that residents of the study area are aware of the causes of flooding. Most people attributed the cause to unplanned urban design, while others signify intense rainfall, river overflow, urbanization as well as occasional release of water from the dam or failure. In evaluating the factors influencing occurrence of floods events, very few respondents are aware of the impact of the site's topography, absence of vegetation and soil nature as important determinants of flood risk. A lot of the participants attributed flooding to poorly channeled drainages, inadequate and clogged existing drainages while another few participant considers violation of planning regulation, failure to heed flood risk warning and building on flood plains important contributors.

\subsection{Equifinality of Flooding}

Bertalanffy (1968) in his book on General System Theory describe equi-finality as "the tendency towards a characteristic final state from different initial states and in different ways, based upon dynamic interaction in an open system". He further explained that the end state is reached independent of the initial conditions and determined only by the system parameters. Hence, the theory implies that in a system capable of interacting with its environment; an end state may be reached from different initial states as shown in figure 4. In other words, different risk factors can lead to the same outcome. 


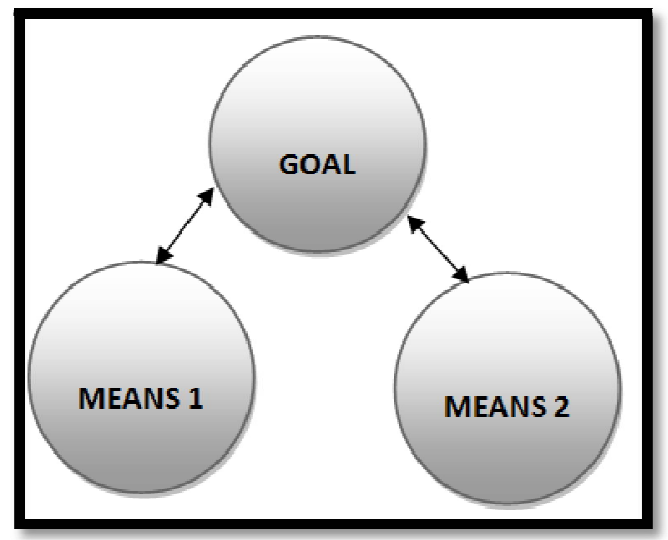

Figure 5: Equi-Finality Triangulation

Source: Kruglanski et.al (2015)

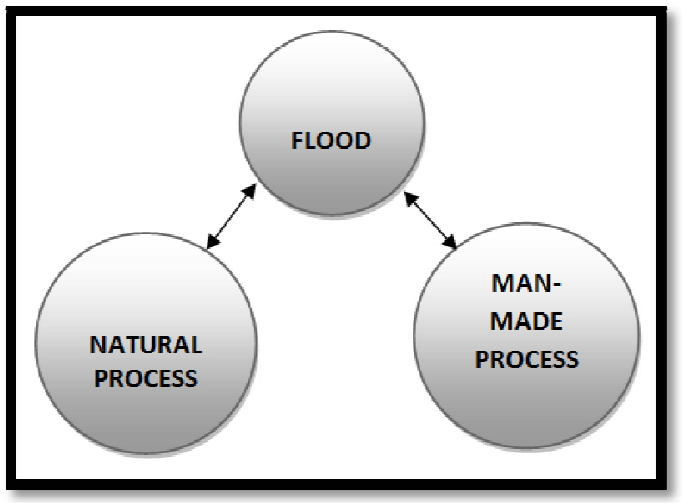

Figure 6: Triangulation of Flooding Source: Author's Survey

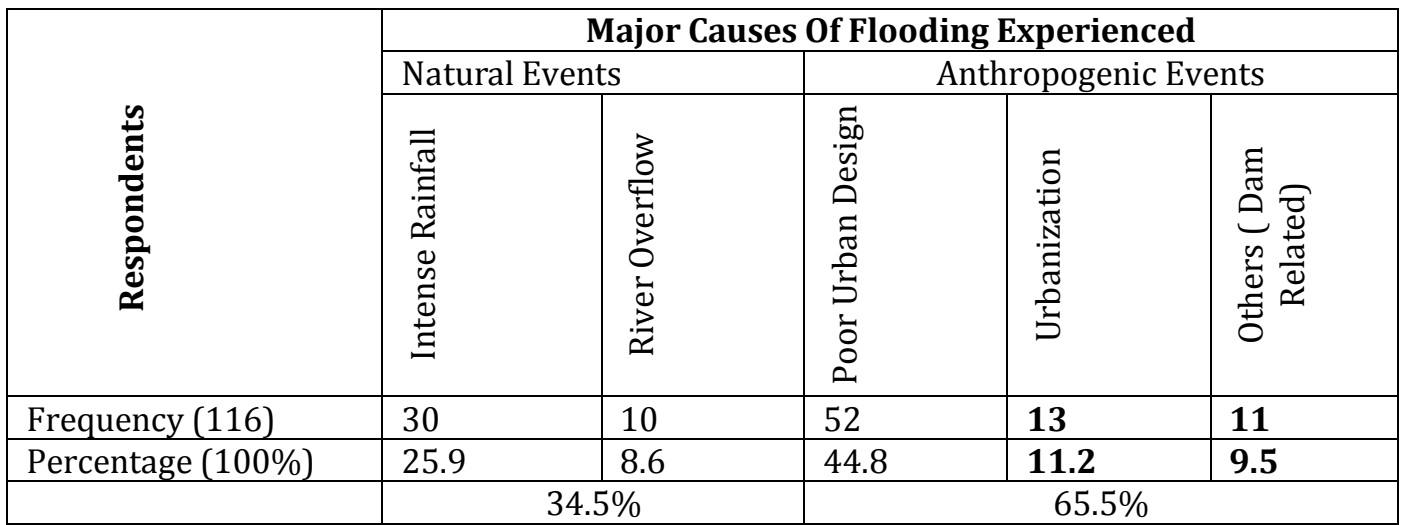

Table 3: Natural and Anthropogenic Processes Causing Flooding in Study Area Source: Author's Field Survey

As analyzed in the Table 3 above, flooding in the study area may be attributed to natural or anthropogenic events. Generally, Lagos has abundant water resources in the form of surface water coupled with a high mean annual rainfall which may naturally induce flooding (Oteri \& Ayeni, 2016). Majority of the areas covered in the survey are located in floodplains which are subject to periodic flooding (Oyinloye et al, 2011). Although the area shares in the rich alluvial soil prominent in the state upon which dense luxuriant undergrowth, climbers, epiphytes and tropical hardwoods grew in the past (www.lagosstate.gov.ng- information for visitors). Today, the natural ecosystem of the area has given way to unplanned urbanization and change in land use augmenting the amount of impermeable surfaces, thus leading to enhanced overland flow and reducing infiltration. The occupation of the indigenous dwellers of Kosofe LGA was matweaving, farming and fishing. Unfortunately, the present day Kosofe is a highly built up residential and commercial area accidental to the once rural community. Houses are built on floodplains and natural water channels. Vegetation whose root system should have intercepted runoffs has been modified to accommodate sprawl associated with growing urban population. The short-sighted design of most existing drainages is inadequate to successfully carry and channel runoffs from intense rain. Currently, poor urban planning coupled with prejudicial anthropogenic activities induces as much floods as natural events.

Using equifinality to explain the flooding issue in the study area, it is clear that floods (end state) occurs independent of intense rainfall (initial condition). While occasional river overflow accompanying intense rainfall coupled 
with the peculiar physical terrain of the study area may explicitly induce flooding. Change in land use; urban expansion; decreased permeability; poor drainage; deforestation and aging infrastructure are strong precursors for flooding.

\begin{tabular}{|c|c|c|c|c|c|c|c|c|c|}
\hline \multirow[b]{3}{*}{ 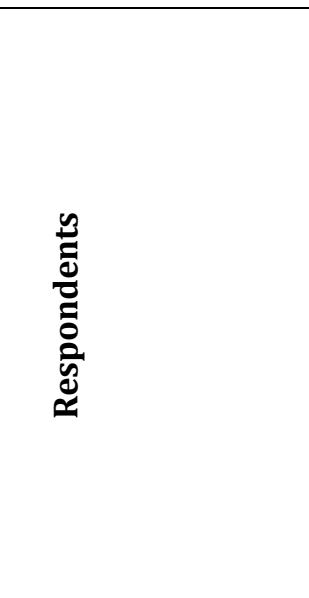 } & \multicolumn{9}{|c|}{ Factors Influencing Occurrence Of Floods } \\
\hline & \multicolumn{3}{|c|}{ Natural Process } & \multicolumn{5}{|c|}{ Human Induced Process } & \multirow[b]{2}{*}{ 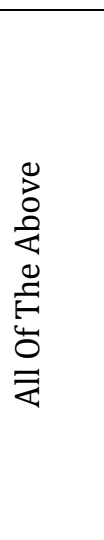 } \\
\hline & 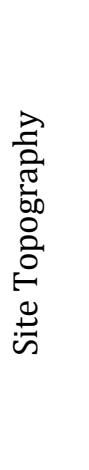 & 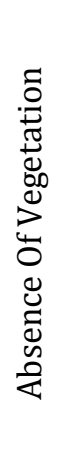 & 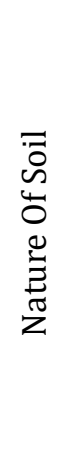 & 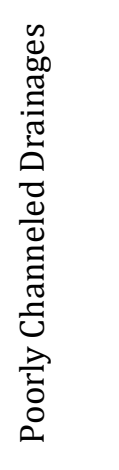 & 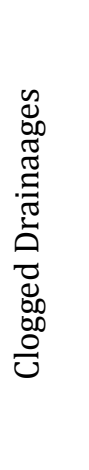 & 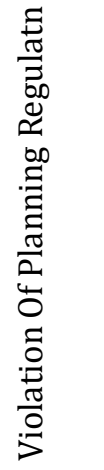 & 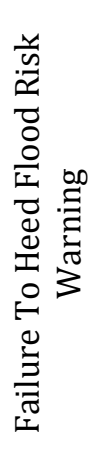 & 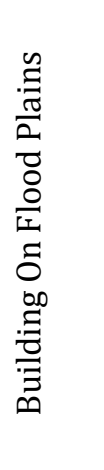 & \\
\hline Frequency (116) & 1 & 3 & - & 66 & 36 & 2 & 1 & 5 & 2 \\
\hline \multirow[t]{2}{*}{ Percentage (100\%) } & 0.9 & 2.6 & - & 56.9 & 31 & 1.7 & 0.9 & 4.3 & 1.7 \\
\hline & \multicolumn{3}{|c|}{$3.5 \%$} & \multicolumn{5}{|c|}{$94.8 \%$} & $1.7 \%$ \\
\hline
\end{tabular}

Table 4: Analysis of Factors Influencing Occurrence of Floods in Study Area

Source: Author's Field Survey

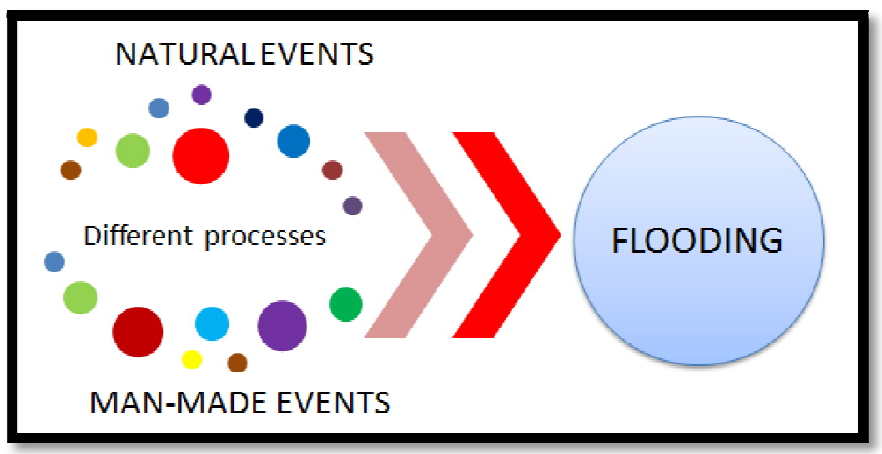

Figure 7: Triangulation of Flooding

\section{Dealing with Urban Expansion and Flood Issue}

Anthropogenic and natural events can independently cause severe environmental problems. We must learn to adapt to natural phenomenon and manage anthropogenic influences in a sustainable way. Urban sprawl is inevitable in cities experiencing rapid urbanization and change in land use associated with this phenomenon particularly in flood prone areas which alters the natural watercourses and leads to increased percentage of impermeable surfaces; reduced infiltration which also affects the nature of run-off experienced. It also affects the natural storage of water and modification of run-off streams (Wheater and Evans 2009). A clear observation from this study is that the factors influencing exposure and vulnerability to floods are directly linked to unplanned urban design. Meanwhile, our cities are not designed to handle flooding.

Also, the uncertainty linked to future weather change impact (rise in sea level and rainfall intensity) calls for a retrospect in adapting to future flood events and our experience of the urban space to secure socio-economic and environmental sustainability.

This starts by understanding that flood is a natural process and that rainwater is a resource which can be recycled and integrated into the urban space (Pallazo, 2019). Urban spaces are not static; they respond to variations in natural processes and should be designed to adapt to eco-social dynamics. Forward thinking urban studies are looking at ways to develop adaptive nature-based design solutions rich in providing co-benefits to climate change such as fresh water storage, biodiversity, water treatment, quality public spaces, etc. (Mendez, 2014).

\section{Conclusions}

This study aims to explore the processes leading to flooding in urbanized wetlands and floodplains, with the goal of fostering an objective understanding of environmental complexities. The general systems theory of equifinality is used to explain the outcomes of the quantitative survey of ten (10) residential communities within Kosofe local government area of Lagos state frequently exposed and vulnerable to floods.

Concerning the attributes of the flooding experienced; most of the area under survey experience flash floods after normal and above normal rainfall of extended duration. Others reported severe home/ compound flooding after intense rainfall. Therefore, provision and network of storm water drains should be emphasized in planning approvals. Also, 
Architects and urban designers should explore vegetation-based intervention on building façade and property to retain extra water. On the neighbourhood scale, measures on floodplain restoration by making space for water should be encouraged within the community.

On the issue of evaluating the causes of flood occurrences, perceived causes of flood tended to be attributed more to anthropogenic activities with poor urban design outlined as the major cause. Urban sprawl and building development within these areas have compromised the natural resiliency of the ecosystems. Hence, flood management should consider redefining and recreating swamps as ecological zones and urban sink. In addition, reforesting areas that have been deforested is suggested. Also, Building developments should also incorporate permeable surfaces that allow water to infiltrate thus reducing runoffs.

On factors influencing occurrence of floods events, human induced processes including poorly channeled drainages, clogged drainages, violation of local planning regulation, failure to heed flood risk warning as well as building on floodplains are considered the major factors. The responses on this particular question showed the low level of awareness on the influence of physical geography and the peculiarity of the wetland ecosystem to flooding. Flood risk education programs should be organized periodically within communities and schools to enhance public perception and preparedness.

On the adaptation of the general systems theory of equifinality to qualitatively explain the quantitative results of the field survey; the theory proved that floods as an end state may occur from different initial states and in different ways, based upon dynamic interaction in the environment. Urban planners and designers are encouraged to develop solutions that intelligently adapts to natural phenomenon and are flexible enough to address social problems.

In conclusion, an objective approach to sustainability is one founded on acknowledging the importance of the ideologies of environmental determinism and possibilism. A profound statement reflecting environmental determinism is that 'the highest development of humankind is characterized by urbanization' (Gerald, 2009). In other words, the environment is the lens through which development is measured. On the other hand, the hallmark of environmental possibilism is the ability to change unfavorable conditions and engineer a favourable environment. While it is common for the environment to set constraints, man has the choice to intelligently journey with sustainability towards a fulfilling and equitable future.

\section{References}

i. Abolade, O., Muili, A. B., \& Ikotun, S. A. (2013). Impacts Of flood disaster in Agege local government area Lagos, Nigeria. Special Issue: Development and Sustainability in Africa - Part 3. International Journal of Development and Sustainability Online ISSN: 2168-8662 - www.isdsnet.com/ijds, Volume 2 Number 4 (2013): Pages 23542367 ISDS Article ID: IJDS13073103

ii. Action Aid. (2006). Climate Change, Urban Flooding and the Rights of the Urban Poor in Africa: Key Findings from Six African Cities, Action Aid International, London.

iii. Adelekan, I. (2013). Private Sector Investment Decision in Building and Construction: Increasing, Managing and Transferring Risks: Case Study of Lagos, Nigeria, The United Nations Office for Disaster Risk Reduction, Global Assessment Report on Disaster Risk Reduction, 1-9, 2013.

iv. Adeloye, A. J. \& Rustum, R. (2011). Lagos (Nigeria) flooding and influence of urban Planning. Urban Design and Planning, 164, 175- 187.

v. Aderogba, K.A. 2012. Global warming and challenges of floods in Lagos metropolis, Nigeria. Academic Research International Vol. 2(1), 448 - 468.

vi. Aderogba, K. (2012a). Qualitative studies of recent flood and sustainable growth and development of cities and towns in Nigeria.International Journal of Academic Research in Economics and Management Science, 1, 1-25.

vii. Ajibade, I., McBean, G., \& Bezner-Kerr, R. (2013). Urban flooding in Lagos, Nigeria: Patterns of Vulnerability and Resilience among women, Global Environ. Change, 23, 1714-1725.

viii. Ajibade, I., Armah, F. A., Kuuire, V. Z., Luginaah, I., McBean, G., \& Tenkorang, E. Y. (2014). Assessing the biopsychosocial correlates of flood impacts in coastal areas of Lagos, Nigeria, J. Environ.

ix. Andrew, S. (2003). Neo-Environmental Determinism, Intellectual Damage Control, and Nature/Society Science. Antipode.35.10.1046/j.1467-8330.2003.00354.x. Retrieved from

https://www.researchgate.net/publication/263518950_NeoEnvironmental_Determinism_Intellectual_Damage _Control_and_Nature_Society_Science

x. Ayoade, J. O., \& Akintola, F. O. (1980). Public perception of flood hazard in two Nigerian cities, Environ. Int., 4, 277-280, 1980.

xi. Beck, J. E. (1985). Environmental determinism in twentieth century American geography: Reflections in the professional journals. University Microfilms International: Dissertation abstracts. (Unpublished Dissertations, University of California, Berkley Call No.: Z5055.U49.I5). 308t 1985188

xii. Bertalanffy, L. V., (1968). General system theory. George Braziller, New York.

xiii. BNRCC (Building Nigeria's Response to Climate Change) (2012). Vulnerability, Impacts and Adaptation, Climate Change in Nigeria, retrieved from www.infoo@climatechange.org

xiv. Creswell, J. W., Plano Clark, V. L., Gutmann, M., \& Hanson, W. (2003). Advanced mixed methods research designs. In A. Tashakkori \& C. Teddlie (Eds.), Handbook of mixed methods in social and behavioral research (pp. 209-240). Thousands Oaks, CA: Sage.Daily Times, Rain causes considerable damage to roads and buildings, 15th Jul. 1947.

xv. Etuonovbe, A. K. (2011). The devastating effect of flooding in Nigeria: FIG Working Week. Retrieved from http://www.fig.net/pub/fig2011/papers/ts06j/ts06j_etuonovbe_5002.pdf 
xvi. Frankel, S. (1992). Geography, Empire, and Environmental Determinism. Geographical Review, Vol. 82(2):143153. Retrieved from https://www.jstor.org/stable/215428.

xvii. George F. M. (2009). The Roles of Environment, Experience, and Learning in Behavioral development. https://doi.org/10.1002/9781444327632.ch6

xviii. Hardin, G. L. (2009). Environmental Determinism: Broken Paradigm or Viable Perspective? Electronic Theses and dissertations. Paper 1839.https://dc.etsu.edu/etd/1839

xix. Kolsrud, G. \& Torrey, B. B. (1991). The importance of population growth in future commercial energy consumption. Global Climate Change, Vol. 45. Retrieved on https://luink.springer.com/chapter/10.1007/9781-4757-2161-4_15

xx. Kruglanski, A. W., Chernikova, M., Babush, M., Dugas, M., \& Schumpe, B. M. (2015). The Architecture of Goal Systems: Multifinality, Equifinality, and Counterfinality in Means-End Relations. In A. J. Elliot (Ed.), Advances in Motivation Science, Elsevier, 3, 69-98. https://doi.org/10.1016/bs.adms.2015.04.001. Retrieved from (http://www.Sciencedirect.com/ science/article/pii/S2215091915000024).

xxi. Mendez, N., L. (2014). Adaptation to Urban Floods by Planning and Design: Guidelines for an adaptive management to urban floods and storm water use taking as a case study the city of Bilbao. Architecture and the Built Environment. Department of Urban Planning and Environment. Urban and Regional Studies, Kth Royal Institute Of Technology

xxii. Nkwunonwo, U.C., Whitworth, M. \& Baily, B. (2016). A review and critical analysis of The efforts towards urban flood risk management in the Lagos region of Nigeria. Natural Hazards and Earth System Sciences, 16, pp. 349369, 2016. DOI: 10.5194/nhess-16-349-2016.

xxiii. Odunuga, S., Oyebande, L., \& Omojola, A. S. (2012). Social-economic indicators and Public perception on urban flooding in Lagos, hydrology for disaster management. Special Publication of the Nigerian Association of Hydrological Sciences, NAHS, Abuja, 82-96.

xxiv. Oshodi, L. (2013). Flood management and governance structure in Lagos, Nigeria, Regions Magazine, 292, 2224.

xxv. Oteri, A. U., \& Ayeni, R. A. (2016). The Lagos Megacity. Water, megacities and global change. Retrieved from https://www.eaumega.org/wp-content/uploads/2016/05/EN-Lagos-Monograph.pdf

xxvi. Oyebande, L. (1974). Drainage protection to urban lands: an environmental challenge, Nigerian Geographical Association Conference, University of Nigeria, Nsukka, Enugu, 1-7.

xxvii. Oyinloye, M., Olamiju, I., \& Adekemi, O. (2013). Environmental Impact of Flooding on Kosofe Local Government Area of Lagos State, Nigeria: A GIS Perspective. Journal of Environment and Earth Science Vol. 3, No.5. ISSN 2224-3216 (Paper) ISSN 2225-0948 (Online). Retrieved from http://www.iiste.org

xxviii. Pallazo. E. (2019). From water sensitive eto floodable: defining adaptive urban design For water resilient cities, Journal of Urban Design, 24:1, 137-157, DOI: 10.1080/13574809.2018.1511972

xxix. Singh, S. (2007). Geography for the UPSC civil services preliminary examination second edition Tata McGrawHill's Series New Delhi.

xxx. Solomon, S. D., Qin, M., \& Manning, Z. (2007). IPCC, Climate Change 2007: The Physical Science Basis, ed. Contribution of Working

xxxi. Group I to the Fourth Assessment Report of the Intergovernmental Panel on Climate Change. Cambridge: Cambridge University Press, 2007

xxxii. Soneye, A. (2014). An overview of humanitarian relief supply chains for victims of perennial flood disasters in Lagos, Nigeria (2010- 2012), Journal of Humanitarian Logistics and Supply Chain Management, 4, 179-197.

xxxiii. UN (United Nations Department of Economic And Social Affairs). (2019). World population prospects 2019: Highlights. Retrievedfrom https://www.un.org/development/desa/publications/world-population-prospects2019-highlights.hmtl

xxxiv. Wang, S. W., Xie, Z. H., Cai, J. N. (2002). Study on the Global Mean Temperature Changes during the last millennium (in Chinese). Prog Nat Sci, 12: 1145-1149.

xxxv. Wheater, H. and Evans, E. 2009. "Land use, water management and future flood risk." Land Use Policy, 26: S251-S264.

xxxvi. WHO (World Health Organization). (2019). Coronavirus disease 2019 (COVID- 19): Situation Report- 101. Retrieved from https://www.who.int/emergencies /diseases/novel-coronavirus-2019/situation-reports.

xxxvii. Zhou, T., Li, B., Man, W., Zhang L., \& Zhang J. (2011). A comparison of the Medieval Warm Period, Little Ice Age and $20^{\text {th }}$ century warming simulated by the FGOALS climate system model: Chinese Science Bulletin, Vol.56

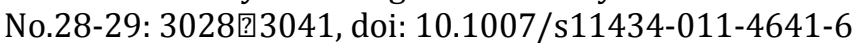

